ORIGINAL ARTICLE
ARTIGO ORIGINAL

\section{Healthcare resource utilization of spinal muscular atrophy in the Brazilian Unified Health System: a retrospective database study}

\author{
Utilização de Recursos em Saúde para pacientes de atrofia \\ muscula espinhal (AME 5q) no Sistema de Saúde Público \\ brasileiro: um estudo retrospectivo em base de dados
}

Julio Barbour ${ }^{1}$, Alexandra Prufer de Queiroz Campos Araújo², Edmar Zanoteli, Marcondes Cavalcante França Jr, Alessandra Mileni Versuti Ritter ${ }^{1}$, Fabiana Casarin, Guilherme Silva Julian ${ }^{1 *}$, Priscila Yazawa ${ }^{5}$, Veronica Elisabeth Mata ${ }^{5}$, Nayara da Silva Carlos ${ }^{5}$

DOI: 10.21115/JBES.v13.n2.p94-107

\section{Keywords}

Spinal muscular atrophy, Unified Health System, rare diseases

\section{Palavras-chave:}

atrofia muscular espinhal, Sistema

Único de Saúde, doenças raras

\begin{abstract}
Objective: To describe the healthcare resource utilization (HCRU) related to patients with spinal muscular atrophy (SMA) treated at the Brazilian Unified Health System (SUS) since 2015 according to age-groups. Methods: This study analyzed outpatient and inpatient data for SMA patients from the Brazilian Unified Health System database (DATASUS) from January 2015 to September 2020. Data were collected from patients with ICD-10 codes G12.0 (Infantile spinal muscular atrophy, type I [Werdnig-Hoffman]) or G12.1 (Other inherited spinal muscular atrophy), plus with at least one claim of nusinersen OR at least one claim of any SMA-related procedure groups codes since 2010. SMA-related procedures were defined based on collaborative work involving authors from medical boarding composed by physicians from SUS. Results: In total, 3,775 patients with SMA fulfilled the eligibility criteria. Physiotherapy changed from $11.34(2.49-24.40)$ procedures PPPY in the 0 - 6-month old group to $3.30(0.84$ - 11.76) procedures PPPY in the $>36$-month old group. The median of orthosis was $1.64(0.66-3.41)$ procedures PPPY in the 0 - 6 -month old group and 0.63 $(0.34-1.33)$ PPPY in the $>36$-month-old group. Exams were primarily performed for younger groups ( 0 - 6 months and $>6-18$ months). The percentage of patients that needed some ventilatory care seems greater, and the speech therapy and the use of nusinersen seem lower along with age. Conclusion: This study has demonstrated important HCRU at the SUS setting with SMA patients. In addition, our results highlight the need to implement evidence-based strategies to manage SMA patients and drive cost savings for the health care system.
\end{abstract}

\section{RESUMO}

Objetivo: Descrever a utilização de recursos em saúde de pacientes com atrofia muscular espinhal (AME) no Sistema Público de Saúde Brasileiro (SUS) desde 2015, de acordo com a faixa etária. Métodos: Analisaram-se os dados hospitalares e ambulatoriais de pacientes com AME no DATASUS de janeiro de 2015 a setembro de 2020. Foram incluídos pacientes com código de CID-10 G12.0 (atrofia muscular espinhal infantil tipo I - Werdning-Hoffman) ou G12.1 (outras atrofias medulares espinhais hereditárias) com pelo menos um registro utilizando o código de nusinersena ou o código de procedimento relacionado à doença desde 2010. Os procedimentos relacionados à doença foram definidos por meio de trabalho colaborativo entre autores, incluindo três autores médicos que atuam no SUS. Resultados: No total, 3.775 pacientes com AME preencheram os critérios de elegibilidade. Procedimentos de fisioterapia passaram de 11,34 $(2,49-24,40)$ por paciente por ano (PPPY) no grupo 0 - 6 meses para 3,30 $(0,84-11,76)$ PPPY no grupo $>36$ meses. A mediada

\footnotetext{
Received on: 03/25/2021. Approved for publication on: 04/02/2021.

1. IQVIA Brazil, São Paulo, SP, Brazil.

2. Federal University of Rio de Janeiro, Neuropediatrics.

3. University of São Paulo - Department of Neurology, Faculty of Medicine.

4. State University of Campinas - Department of Neurology.

5. Roche Brazil, São Paulo, SP, Brazil.

*Reprint requests and correspondence should be addressed to:

Corresponding author: Nayara da Silva Carlos, BPharm, MSC. Av. Eng. Billings, 1729. CEP: 05321-900 - São Paulo-SP - Brazil. E-mail: nayara.carlos@roche.com. Phone: +55 11 98331-5235
} 
de procedimentos de órteses foi de 1,64 (0,66 - 3,41) PPPY no grupo 0 - 6 meses para 0,63 $(0,34$ - 1,33) PPPY no grupo > 36 meses. Exames foram realizados principalmente por pacientes mais jovens ( 0 - 6 meses e $>6$ - 18 meses). A porcentagem de pacientes que realizaram procedimentos ventilatórios parece aumentar ao longo da idade, já a fonoterapia e o uso de nusinersena parecem reduzir. Conclusão: Este estudo demonstra uma importante utilização de recursos em saúde no SUS pelos pacientes com AME e destaca a necessidade de implementação de estratégias baseadas em evidência para gerenciar esses pacientes e o uso de recursos no sistema de saúde.

\section{Introduction}

Spinal muscular atrophy (SMA) is a genetic disease characterized by weakness and progressive muscular atrophy caused by motor neuron degeneration. SMA is the most common genetic cause of death in infants (Arnold et al., 2015; Verhaart et al., 2017). To date, only a few studies have assessed the prevalence and incidence of SMA. Most of them have been conducted before the disease-causing gene had been identified and treatment available. According to a review study, an estimation of the incidence of all types of SMA of around 10 in 100,000 live births is reported in Europe (Mercuri et al., 2018; Verhaart et al., 2017).

The predominant clinical features of SMA patients are motor dysfunctions, affecting the ability to sit, walk and perform daily activities, which can progress with respiratory dysfunction and failure (Arnold et al., 2015). The clinical and economic impact varies according to the severity, clinically classified in four main phenotypes (SMA type I-IV) according to the age at onset and maximum motor function achieved (Arnold et al., 2015; Lunn \& Wang, 2008; Verhaart et al., 2017).

SMA type I is the most common type of SMA (Arnold et al., 2015), and starts before six months of age, with a life expectancy shorter than two years, if untreated. SMA type II begins at 7-18 months of age, with a longer life expectancy than type I. Generally, there is a progressive severity of signs and symptoms, mainly affecting the respiratory system, leading to respiratory failure and requiring ventilatory support (Kim et al., 1999; Lunn \& Wang, 2008; Verhaart et al., 2017). About $30 \%$ of patients have SMA type III (Arnold et al., 2015), and the disease onset starts after 18 months of age. Unlike types I and II, the life expectancy of SMA type III patients is similar to healthy people (Kim et al., 1999; Lunn \& Wang, 2008; Verhaart et al., 2017). Type IV is the least severe form, with the disease onset occurring after 20 - 30 years old or late (Darbà \& Marsà, 2019; Verhaart et al., 2017).

Managing symptoms of SMA often requires a large amount number of healthcare resources. Precisely designed supportive, rehabilitative, and palliative care can partly reduce the disease burden and change the natural history. Patients usually seek physiotherapy, medical consultation, mechanical ventilation, electric wheelchair, symptomatic pharmacological drugs They usually require hospitalization, orthopedic rehabilitation, and surgeries along the disease course (Darbà,
2020; Darbà \& Marsà, 2019; Droege et al., 2020). Disease burden is somewhat specific to the SMA type, with more severe subtypes requiring more intensive management. The healthcare team and family's proactive care and treatment decision-making are of utmost importance (Arnold et al., 2015). Regarding costs, the economic impact on SMA patients, and their care has only been partially evaluated in Brazil.

Brazil has a comprehensive public healthcare system (SUS, Sistema Único de Saúde [Unified Health System]) available for the entire population, where SMA patients can be treated. Healthcare is free of charge for the patient, being financed by the Brazilian government. A private system also exists, but only around $22 \%$ of the population has access to it due to its cost (ANS, 2021). Understanding the resources imposed by SMA healthcare in real-world setting is essential for adequately informing and designing public policies and funding decisions regarding health interventions and service planning. It is more relevant in the current scenario with emerging therapeutic approaches (Chambers et al., 2020), such disease-modifying drugs as nusinersen, onasemnogene abeparvovec and risdiplam. Nowadays, nusinersen is the only SMA drug incorporated by SUS (CONITEC, 2019). There is limited information on healthcare resource utilization of patients diagnosed with SMA treated at the Brazilian Unified Health System. Therefore, this study aims to provide updated and real-world estimations of healthcare resource utilization of patients with SMA treated in public institutions.

\section{Material and methods}

This study was based on secondary data from DATASUS database of SMA patients treated in outpatient and inpatient settings from January 2015 to September 2020. Patients with SMA treated in public settings were selected considering the International Classification of Diseases, 10th revision (ICD-10) codes: G12.0 (Infantile spinal muscular atrophy, type I [WerdnigHoffman]) or G12.1 (Other inherited spinal muscular atrophy), plus at least one claim of any SMA-related procedure groups codes $O R$ at least one claim of nusinersen use.

The definition of SMA-related procedures resulted from a collaborative work involving authors from a medical boarding, as described: 1. An external medical board composed of three neurologists worked together with other 
authors to define all the main SMA-related procedures in outpatient and inpatient settings; 2 . Based on step 1, a medical expert evaluated all procedures associated with ICD-10 codes G12.0 and G12.1 in the DATASUS database, to select the most prevalent procedures; 3 . Collected information on standard procedures performed on SMA patients and those performed before and after the disease diagnosis were then revalidated with the external medical boarding, who defined the SMA-related procedures. The SMA-related procedure was composed by:

- 0301050015 - Domestic assessment of patient submitted to non-invasive mechanical ventilation patient/month

- 0404010377 - Tracheostomy

- 0301100071 - Tracheostomy care

- 0407010211 - Gastrostomy

- 0407010220 - Videolaparoscopic gastrostomy

- 0408060468 - Tenomyotomy/ disinsertion

- 0701010029 - Adult/infantile wheelchair (standard type)

- 0701020067 - Infantile orthosis for limiting knee with articulated extension

- 0701020075 - Infantile orthosis for limiting knee movements

- 0701020083 - Orthosis with distractor (infantile and juvenile)

- 0701020210 - Infantile orthosis articulated

- 0701020229 - Orthosis without articulation (adult)

- 0701020237 - Orthosis without articulation (infantile)

- 0301010196 - Clinical evaluation for the diagnosis of rare disease - axis I - 1 - congenital or long manifestation anomalies

- 0201010631 - Lumbar puncture

- 0309010039 - Percutaneous endoscopic gastrostomy

- 0604790015 - Nusinersen 2,4MG/ML injection solution

For the analysis, we adopted two strategies: a) Categorization of SMA patients according to age groups at the first claim with ICD-10 codes G12.0 or G12.1, considering age groups of $0-<2$ years, $2-<6$ years, $6-11$ years, $12-17$ years, $18-25$ years and $26+$ years; and, b) Categorization of SMA patients according to age at first SMA-related procedure claim, considering age groups of up to 6 months, $>6-18$ months, $>18-36$ months and $>36$ months. The current age was calculated based on the patient's date of birth until the date of analysis (January 2021) and was presented according to the age group: 0 - $<2$ years, $2-<6$ years, $6-11$ years, $12-17$ years, $18-25$ years and $26+$ years.

For healthcare resource utilization analysis, we categorized SMA patients in different age groups ( 0 - 6 months, $>6$ - 18 months, $>18$ - 36 months, and >36 months) according to the age at the first claim of main clinical procedures performed on SMA patients found in DATASUS databases. The definition of a patient's follow-up time was based on the first claim of SMA (ICD-10 G12.0 or G12.1) or SMA-related procedures, up to their last claim in the database.

\section{Data source}

The data source for this study was the DATASUS databases. DATASUS is held by the Brazilian Ministry of Health Department of Informatics and provides data from procedures performed within the Brazilian Unified Health System (SUS), covering a critical number of Brazilian populations. The administrative data is presented as procedure codes from billing records and includes demographic information, all outpatient and inpatient procedures, number and type of procedures, diagnosis code using ICD-10, and other additional information. All outpatient or inpatient procedures in SUS follow the standardized procedure list SIGTAP [System for the Management of the Pricing List of Procedures, Drugs, and OPM (orthoses, prostheses, and materials) of SUS].

Information used in this study was collected from DATASUS two databases: SIH (Sistema de Informações Hospitalares [Inpatient Information System]), containing data on inpatient procedures. It provides data on hospitalization, information on causes, performed procedures, and costs of the healthcare resources utilized; and SIA (Sistema de Informações Ambulatoriais [Outpatient Information System]), containing data on outpatient procedures. All high complexity procedures will rely on this SIA data, and some mid-low complexity outpatient procedures may be available too. There is minimal information on primary care.

The SIA system has an encrypted and anonymized patient ID code that links the outpatient procedures to a single patient. However, SIH does not have patient ID information. Thus a probabilistic record linkage among SIA and SIH information was performed to allow longitudinal assessment, using multiple steps with different combinations of patient data from both databases, as previously described (Campos et al., 2017) (Julian et al., 2020).

\section{Population}

Patients were included in the study if they had at least one claim of SMA-specific ICD-10 codes (G12.0 or G12.1) plus at least one claim of nusinersen use OR any SMA-related procedure codes since 2010. A minimum of 30 days of follow-up in the database since 2015 was also required. Since SMA is a chronic disease, this approach should exclude individuals with a false diagnosis. Otherwise, no information or other relevant aspects for the patient would be available. Patients with excessive missing or inconsistent data (e.g. date of birth) were automatically excluded from the analysis. Considering the limitation of administrative claims database analysis, including the lack and the inconsistent use of ICD-10 diagnosis code for SMA, only patients with both claims were included in this study to mitigate the risk of misclassification. The healthcare resource data was 
collected since 2015 from SMA patients who fulfilled the eligibility criteria.

\section{Index date}

The index date was defined as the date of the first claim of SMA-specific ICD-10 codes (G12.0 or G12.1) or the first claim of any SMA-related procedure group codes before SMA-specific ICD-10 codes at the database since 2010.

The age of the first occurrence of SMA-related procedure codes was used to define the age of symptoms, and the age of the first claim of SMA-specific ICD-10 codes (G12.0 or G12.1) was used to determine the age of diagnosis.

\section{Outcomes}

The study's primary outcomes have described healthcare resources used on SMA patients, both at outpatient and inpatient settings, and a description of SMA patient's demographic and clinical characteristics. According to procedure-groups and per age-group, results were calculated considering the procedures performed during the last year (October 2019 September 2020) represented by moving annual total (MAT) and since 2015 to the previous data available per patient.

All-cause medical services were defined as healthcare resources associated with any condition incurred in the outpatient setting. For the inpatient setting, only healthcare resources related to SMA ICD-10 codes were included. Healthcare resource utilization covered different claims groups and was presented as: gastric, respiratory, and muscular procedures (tracheostomy, tenomyotomy, and gastrostomy), physiotherapy, medical consultation, treatment/drug, wheelchair uses, and orthoses.

The different claim groups were composed by specific SMA-related procedures defined according to the SIGTAP table, as disclaimed in Table 1. The exploratory objective was to describe and count the SMA-related procedures performed on SMA patients, both in outpatient and inpatient settings, per age-group.

The different claim groups were composed by specific SMA-related procedures defined according SIGTAP table, as disclaimed in Table 1. The exploratory objective was the description and count of main SMA-related procedures performed by the SMA patients, both outpatient and inpatient settings, per age-group.

The demographic and clinical characteristics were described for all SMA patients. It included age at the first claim of SMA; gender distribution (percentage); residence (Brazilian

Table 1. Group of SMA-related procedures composed of each specific procedure defined according to the SIGTAP table

\begin{tabular}{|c|c|c|}
\hline SMA-related procedure group & Procedure code & Procedure name \\
\hline \multirow{10}{*}{$\begin{array}{l}\text { Gastric, respiratory and } \\
\text { muscular procedures }\end{array}$} & 0301050015 & Monitoring and evaluation of patient submitted to non-invasive mechanical ventilation \\
\hline & 0301050066 & Implementation or maintenance of home non-invasive mechanical ventilation \\
\hline & 0309010039 & Gastrostomy endoscopic percutaneous \\
\hline & 0404010377 & Tracheostomy \\
\hline & 0412010127 & Tracheostomy with the placement of tracheal orthosis or tracheobronchial \\
\hline & 0301100071 & Tracheostomy care \\
\hline & 0408060468 & Tenomyotomy/disinsertion \\
\hline & 0309010039 & Endoscopy gastrostomy \\
\hline & 0407010211 & Gastrostomy \\
\hline & 0407010220 & Videolaparoscopic gastrostomy \\
\hline \multirow[t]{6}{*}{ Physiotherapy } & 0301070121 & $\begin{array}{l}\text { Intensive patient treatment in physical rehabilitation ( } 1 \text { patient-day break - } 20 \text { months } \\
\text { care) }\end{array}$ \\
\hline & 0302060014 & $\begin{array}{l}\text { Physiotherapy assistance in patients with neuro-kinetic-functional disorders without } \\
\text { systemic complications }\end{array}$ \\
\hline & 0302060022 & $\begin{array}{l}\text { Physiotherapy assistance in patients with neuro-kinetic-functional disorders with } \\
\text { systemic complications }\end{array}$ \\
\hline & 0302060030 & Physiotherapy assistance in disorders of neuromotor development \\
\hline & 0302040013 & Physiotherapy service in patients with respiratory disorders and systemic complications \\
\hline & 0302050027 & Physiotherapy service in motor changes \\
\hline Speech therapy & 0301070113 & Individual speech therapy \\
\hline Medical Consultation/Care & 0301010196 & $\begin{array}{l}\text { Clinical evaluation for the diagnosis of rare disease - AXIS I - congenital or late } \\
\text { manifestation anomalies. Comprises clinical and laboratory assessment (laboratory tests } \\
\text { described at exams topic) }\end{array}$ \\
\hline
\end{tabular}




\begin{tabular}{|c|c|c|}
\hline & 0301010072 & Medical consultation in specialized care \\
\hline & 0301010064 & Medical consultation in primary care \\
\hline & 0301010137 & Consultancy/homecare service \\
\hline & 0301010161 & Consultancy/advice at the specialized care \\
\hline & 0301050074 & Homecare \\
\hline & 0301060010 & Diagnose and/or urgency assessment In a pediatric clinic \\
\hline & 0303040190 & Treatment of central neurons with or without amyotrophic diseases \\
\hline & 0802010024 & Accompanying child daily \\
\hline & 0802010199 & Inpatient Long daily (longer than expected) \\
\hline & 0303040203 & Treatment of neurodegenerative disease \\
\hline Treatment/drug & 0604790015 & Nusinersen 2,4MG/ML injection solution \\
\hline \multirow[t]{8}{*}{ Wheelchair use } & 0701010029 & Adult/child wheelchair (standard type) \\
\hline & 0701010207 & Monoblock wheelchair \\
\hline & 0701010223 & Adult or infantile motorized wheelchair \\
\hline & 0701010231 & Wheelchair for children in shell \\
\hline & 0701010240 & Wheelchair with a reclining surface \\
\hline & 0701010258 & Wheelchair for bath \\
\hline & 0701010037 & Wheelchair for bath with health seat \\
\hline & 0701010045 & Wheelchair for quadriplegic standard type \\
\hline \multirow[t]{9}{*}{ Orthoses } & 0701020067 & Orthosis infantile for limiting knee with articulated extension \\
\hline & 0701020075 & Infantile orthosis for limiting knee movements \\
\hline & 0701020083 & Orthosis with distractor (infantile and juvenile) \\
\hline & 0701020210 & Infantile orthoses articulated \\
\hline & 0701020229 & Orthosis without articulation (adult) \\
\hline & 0701020237 & Orthosis without articulation (infantile) \\
\hline & 0701090014 & Orthosis Philadelphia type for immobilization of the cervical region \\
\hline & 0701020245 & Orthosis metallic (adult) \\
\hline & 0701020180 & Orthosis metallic with or without ischial base (infantile and juvenile) \\
\hline \multirow{7}{*}{ SMA-related tests } & 0202100111 & Identification of mutation by amplicon sequencing up to 500 pairs of bases \\
\hline & 0202100065 & DNA analysis by Southern blot technique \\
\hline & 0202100073 & DNA analysis by MLPA - multiplex ligation-dependent probe amplification \\
\hline & 0202100081 & $\begin{array}{l}\text { Identification of mutation/rearrangements by } P C R \text {, sensitive } P C R \text {, measurement, } \mathrm{APCR} \\
\text { and qPCR sensitive to methylation }\end{array}$ \\
\hline & 0202100090 & FISH in metaphase or interphasic nucleus, per disease \\
\hline & 0202100103 & Identification of submicroscopic chromosomic change by array-CGH \\
\hline & 0201010631 & lumbar puncture \\
\hline
\end{tabular}

regions - south, southeast, north, northeast, central-west); and follow-up period.

\section{Statistical analysis}

This retrospective administrative claim database analysis explored the healthcare resource utilization related to patients with SMA treated at SUS since 2015 according to the agegroup. Data available at the DATASUS website were handled using Python.
The analyses of the primary and secondary outcomes were performed using descriptive statistics for age-stratified cohorts. The SMA-procedures were mainly expressed as the average number of SMA-related procedures MAT per patient and per procedures done since 2015 to the last data available. Since each individual attends a different amount of time in the database, the SMA-related procedures were converted to per patient/per year units dividing them for all patients by the person-year follow-up. 
Demographic data, outpatient and inpatient procedures, and healthcare resource consumption were analyzed descriptively. Data are reported as continuous variables (quantitative ones) and were summarized by mean, median, standard deviation (SD), interquartile range (IQR), minimum and maximum for continuous variables. Frequency and percentages were reported for categorical variables.

\section{Ethical aspects}

Data available in DATASUS are anonymized and encrypted and made available publicly. In addition, according to the Brazilian ethics Resolution No. 510 from April 7, 2016, studies of public domain information do not require approval from ethics committees (Conselho Nacional de Saúde, 2016, n.d.).

Table 2. Number of new cases of SMA patients diagnosed per calendar year

\begin{tabular}{lcc}
\hline Period at first SMA claim & N & $\%$ \\
\hline 2010 & 331 & 8.77 \\
\hline 2011 & 451 & 11.95 \\
\hline 2012 & 405 & 10.73 \\
\hline 2013 & 374 & 9.91 \\
\hline 2014 & 381 & 10.09 \\
\hline 2015 & 447 & 11.84 \\
\hline 2016 & 310 & 8.21 \\
\hline 2017 & 358 & 9.48 \\
\hline 2018 & 343 & 9.09 \\
\hline 2019 & 270 & 7.15 \\
\hline $2020^{*}$ & 105 & 2.78 \\
\hline Total & 3,775 & \\
\hline
\end{tabular}

* 2020 - incomplete year (up to September 2020)

Table 3. Demographic characteristics

\begin{tabular}{lc}
\hline Gender, N (\%) & $1,682(44.56)$ \\
\hline Female & $2,093(55.44)$ \\
\hline Male & $1,574(41.70)$ \\
\hline Region of residence, N (\%) & $545(14.44)$ \\
\hline Southeast & $229(6.07)$ \\
\hline South & $1,328(35.18)$ \\
\hline Midwest & $99(2.62)$ \\
\hline Northeast & \\
\hline North & $4.57(2.77)$ \\
\hline Age at index date, years & $4.51(2.10,6.84)$ \\
\hline Median (IQR) & \\
\hline Follow-up*, years & \\
\hline Mean (SD) &
\end{tabular}

SD: standard deviation; IQR: interquartile range

\section{Results}

In the database, we identified 3,775 SMA patients meeting the eligibility criteria (Table 2).

Patient demographic characteristics are presented for the overall study population in Table 3. On the index date, the median age of patients was 13.4 ( $3-48$ years), and the mean length of follow-up was 4.51 (2.1 - 6.8) years. The cohort had slightly more males (55.4\%) than females (44.6\%), with a heterogeneous geographic distribution around the country. The majority of SMA patients were localized in the Southeast (41.6\%) and Northeast (35.3\%), followed by the South (14.5\%), Midwest (6.0\%), and North (2.6\%) areas.

\section{The outcome from patients identified in DATASUS since 2015 (from January 2015 to September 2020) $(N=3,775)$}

SMA patients treated at SUS categorized by age-group at the first claim of SMA-specific ICD-10 and the current age group are shown in Table 4. Of the 3,775 patients identified in the DATASUS database, $19.55 \%$ were diagnosed before two years old, $16.19 \%$ between $2-<6$ years, $10.52 \%$ between 6 - 11 years, 8.13\% between $12-17$ years, 5.99\% between $18-25$ years and $39.63 \%$ over 26 years old according to the SMA ICD-10 specific code. Six groups were defined concerning each patient's current age. At the current date (January 2021), 44\% of the patients are over 26 years old and $2 \%$ less than two years old. All patients diagnosed with SMA before six years old $(0-<2$ years old group and $2->6$ years old group) are younger than 18 years old at current date (Table 3). None of those diagnosed before the age of 2 years are older than 18 years at present, and only $1 \%$ is in the range of 12 to 17 years old.

When considering the age of the first claim of SMArelated procedure in DATASUS with the current age (Table 5), $5.30 \%$ of the patients presented the first claim before six months old. Of those, $0.90 \%$ are aged $0->2$ years, $2.54 \%$ are aged $2->6$ years and $1.85 \%$ are aged $6-11$ years at current date. The vast majority of SMA patients (75\%) presented the first claim after 36 months old, distributed among $0 \%, 0.90 \%$, $6.60 \%, 12.03 \%, 11.10 \%$, and $44.05 \%$ to the different current age groups.

\section{The outcome from patients identified in DATASUS in the last year (from October 2019 to September 2020) $(N=2,137)$}

According to the current age group, data from October 2019 to September 2020 about SMA patients treated at SUS categorized by age-group at the first claim of SMA-specific ICD10 and the first claim of SMA-related procedure according to the current age group are shown in Table 6 and Table 7, respectively. Altogether, 2,137 patients were identified in the DATASUS database in this period. Of those, $22.46 \%$ of SMA patients were diagnosed before two years old, $17.50 \%$ between $2-<6$ years, 10.81\% between $6-11$ years, 7.96\% between 
Table 4. The number of SMA patients treated at SUS, according to the age at the first claim of SMA-specific ICD-10 code and the current age (data since 2015)

\begin{tabular}{|c|c|c|c|c|c|c|c|}
\hline \multirow{2}{*}{$\begin{array}{l}\text { Age at the first claim of } \\
\text { SMA ICD-10 code, N (\%) }\end{array}$} & \multicolumn{7}{|c|}{ Current age (January 2021) } \\
\hline & $0-<2$ years & $2-<6$ years & $6-11$ years & $12-17$ years & $18-25$ years & $>26$ years & All \\
\hline $0-<2$ years & $80(2.12)$ & $295(7.81)$ & $339(8.98)$ & $24(0.64)$ & - & - & 738 (19.55) \\
\hline $2-<6$ years & - & $88(2.33)$ & $302(8.0)$ & $221(5.85)$ & - & - & $611(16.19)$ \\
\hline $6-11$ years & - & - & $66(1.75)$ & $216(5.72)$ & $115(3.05)$ & - & $397(10.52)$ \\
\hline $12-17$ years & - & - & - & $62(1.64)$ & $226(5.99)$ & $19(0.50)$ & $307(8.13)$ \\
\hline $18-25$ years & - & - & - & - & $78(2.07)$ & $148(3.92)$ & $226(5.99)$ \\
\hline$>26$ years & - & - & - & - & - & $1,496(39.63)$ & $1,496(39.63)$ \\
\hline All & $80(2.12)$ & $383(10.15)$ & 707 (18.73) & $523(13.85)$ & $419(11.10)$ & $1,663(44.05)$ & $3,775(100.0)$ \\
\hline
\end{tabular}

Table 5. The number of SMA patients treated at SUS, according to the age at the first claim of SMA-related procedure and the current age (data since 2015)

\begin{tabular}{|c|c|c|c|c|c|c|c|}
\hline \multirow{2}{*}{$\begin{array}{l}\text { Age at the first claim of } \\
\text { SMA-related procedure, } \\
\mathrm{N}(\%)\end{array}$} & \multicolumn{7}{|c|}{ Current age (January 2021) } \\
\hline & $0-<2$ years & $2-<6$ years & $6-11$ years & $12-17$ years & $18-25$ years & $>26$ years & All \\
\hline $0-6$ months & $34(0.90)$ & $96(2.54)$ & $70(1.85)$ & - & - & - & $200(5.30)$ \\
\hline$>6-18$ months & $44(1.17)$ & $139(3.68)$ & $200(5.30)$ & $9(0.24)$ & - & - & $392(10.38)$ \\
\hline$>18-36$ months & $2(0.05)$ & $114(3.02)$ & $188(4.98)$ & $60(1.59)$ & - & - & $364(9.64)$ \\
\hline$>36$ months & - & $34(0.90)$ & $249(6.60)$ & $454(12.03)$ & $419(11.10)$ & $1,663(44.05)$ & 2,819 (74.68) \\
\hline All ages & $80(2.12)$ & $383(10.15)$ & 707 (18.85) & $523(13.85)$ & $419(11.10)$ & $1,663(44.05)$ & $3,775(100.0)$ \\
\hline
\end{tabular}

Table 6. The number of SMA patients treated at SUS, according to the first claim of SMA-specific ICD-10 code and current age (data from October 2019 to September 2020).

\begin{tabular}{|c|c|c|c|c|c|c|c|}
\hline \multirow{2}{*}{$\begin{array}{l}\text { Age at the first claim of } \\
\text { SMA ICD-10 code, N (\%) }\end{array}$} & \multicolumn{7}{|c|}{ Current age (January 2021) } \\
\hline & $0-<2$ years & $2-<6$ years & $6-11$ years & $12-17$ years & $18-25$ years & $>26$ years & All \\
\hline $0-<2$ years & $80(3.74)$ & $211(9.87)$ & $182(8.52)$ & $7(0.33)$ & - & - & $480(22.46)$ \\
\hline $2-<6$ years & - & $81(3.79)$ & $192(8.98)$ & $101(4.73)$ & - & - & $374(17.50)$ \\
\hline $6-11$ years & - & - & $59(2.76)$ & $122(5.71)$ & $50(2.34)$ & - & $231(10.81)$ \\
\hline $12-17$ years & - & - & - & $46(2.15)$ & $117(5.47)$ & $7(0.33)$ & $170(7.96)$ \\
\hline $18-25$ years & - & - & - & - & $48(2.25)$ & $68(3.18)$ & $116(5.43)$ \\
\hline$>26$ years & - & - & - & - & - & $766(35.84)$ & $766(35.84)$ \\
\hline All & $80(3.74)$ & $292(13.66)$ & $433(20.26)$ & $276(12.92)$ & $215(10.06)$ & $841(39.35)$ & $2,137(100.00)$ \\
\hline
\end{tabular}

Table 7. The number of SMA patients treated at SUS, according to the first claim of SMA-related procedure and current age (data from October 2019 to September 2020).

\begin{tabular}{|c|c|c|c|c|c|c|c|}
\hline \multirow{2}{*}{$\begin{array}{l}\text { Age at the first claim of } \\
\text { SMA-related procedure, } \\
\mathrm{N}(\%)\end{array}$} & \multicolumn{7}{|c|}{ Current age (January 2021) } \\
\hline & $0-<2$ years & $2-<6$ years & $6-11$ years & $12-17$ years & $18-25$ years & $>26$ years & All \\
\hline $0-6$ months & $34(1.59)$ & $57(2.67)$ & $34(1.59)$ & - & - & - & $125(5.85)$ \\
\hline$>6-18$ months & $44(2.06)$ & $106(4.96)$ & $113(5.29)$ & $3(0.14)$ & - & - & $266(12.45)$ \\
\hline$>18-36$ months & $2(0.09)$ & $96(4.49)$ & $96(4.49)$ & $21(0.98)$ & - & - & $215(10.06)$ \\
\hline$>36$ months & - & $33(1.54)$ & $190(8.89)$ & $252(11.79)$ & $215(10.06)$ & $841(39.35)$ & $1,531(71.64)$ \\
\hline All ages & $80(3.74)$ & $292(13.66)$ & $433(20.26)$ & $276(12.92)$ & $215(10.06)$ & $841(39.35)$ & $2,137(100.00)$ \\
\hline
\end{tabular}

12 - 17 years, 5.43\% between 18 - 25 years, and $35.84 \%$ over 26 years old, according to the SMA ICD-10 specific code (Table 6). 5.85\% of patients underwent the first SMAprocedure between 0 - 6 months old, $12.45 \%$ between $>6$ - 18 months, $10.06 \%$ between $>18$ - 36 months, and $71.64 \%$ over $>36$ months old (Table 7).

\section{Healthcare resource utilization per SMA-related procedure group}

In each subset of SMA, the number of claims was described over the study period based on the mean and the median number of procedures performed per patient during the last year - MAT (Table 8) and per patient per year - PPPY, 
Table 8. HCRU - SMA-related procedure groups, per patient per year, pooled by age at the first claim during the last year (October 2019 to September 2020) (N: 2,137)

\begin{tabular}{|c|c|c|c|c|}
\hline Outpatient & $0-6$ months & $>6-18$ months & $>18-36$ months & $>36$ months \\
\hline Total of Patient (N) & 125 & 266 & 215 & 1531 \\
\hline \multicolumn{5}{|c|}{ Ventilatory care/gastrostomy } \\
\hline $\mathrm{N}^{*}(\%)$ & $5(4.00)$ & $23(8.65)$ & $24(11.16)$ & $224(14.63)$ \\
\hline Mean (SD) & $10.40(2.61)$ & $7.13(3.65)$ & $8.58(3.74)$ & $10.05(2.75)$ \\
\hline Median (IQR) & $11.00(11.00-11.00)$ & $7.00(4.50-11.00)$ & $11.00(5.00-11.00)$ & $11.00(11.00-11.00)$ \\
\hline \multicolumn{5}{|l|}{ Physiotherapy } \\
\hline$N^{*}(\%)$ & $65(52.00)$ & $116(43.61)$ & $114(53.02)$ & $618(40.37)$ \\
\hline Mean (SD) & $9.03(8.72)$ & $9.86(10.23)$ & $11.06(21.31)$ & $8.49(14.86)$ \\
\hline Median (IQR) & $7.00(2.00-12.00)$ & $6.00(3.00-13.00)$ & $5.00(2.00-10.00)$ & $4.00(2.00-9.00)$ \\
\hline \multicolumn{5}{|l|}{ Speech therapy } \\
\hline $\mathrm{N}^{*}(\%)$ & $27(21.60)$ & $46(17.29)$ & $28(13.02)$ & $135(8.82)$ \\
\hline Mean (SD) & $4.22(4.06)$ & $7.85(8.59)$ & $7.00(11.53)$ & $4.49(3.84)$ \\
\hline Median (IQR) & $3.00(1.00-5.00)$ & $4.00(1.25-12.75)$ & $3.00(2.00-8.25)$ & $3.00(2.00-6.00)$ \\
\hline \multicolumn{5}{|l|}{ Medical Care } \\
\hline$N^{*}(\%)$ & $23(18.40)$ & $43(16.17)$ & $29(13.49)$ & $174(11.37)$ \\
\hline Mean (SD) & $2.48(1.70)$ & $2.70(2.71)$ & $2.72(2.46)$ & $2.62(2.28)$ \\
\hline Median (IQR) & $2.00(1.00-3.00)$ & $2.00(1.00-3.00)$ & $2.00(1.00-3.00)$ & $2.00(1.00-3.00)$ \\
\hline \multicolumn{5}{|l|}{ Drugs } \\
\hline $\mathrm{N}^{*}(\%)$ & $19(15.20)$ & $39(14.66)$ & $21(9.77)$ & $21(1.37)$ \\
\hline Mean (SD) & $3.32(1.53)$ & $3.95(1.97)$ & $3.10(1.58)$ & $3.62(1.60)$ \\
\hline Median (IQR) & $3.00(2.00-4.00)$ & $3.00(3.00-5.00)$ & $3.00(2.00-4.00)$ & $3.00(3.00-4.00)$ \\
\hline \multicolumn{5}{|l|}{ Wheelchair } \\
\hline $\mathrm{N}^{*}(\%)$ & $7(5.60)$ & $26(9.77)$ & $27(12.56)$ & $154(10.06)$ \\
\hline Mean (SD) & $1.86(1.07)$ & $1.65(0.75)$ & $2.04(1.13)$ & $1.85(1.00)$ \\
\hline Median (IQR) & $2.00(1.00-2.00)$ & $1.50(1.00-2.00)$ & $2.00(1.00-2.00)$ & $2.00(1.00-2.00)$ \\
\hline \multicolumn{5}{|l|}{ Orthosis } \\
\hline$N^{*}(\%)$ & $13(10.40)$ & $31(11.65)$ & 35 (16.28) & $60(3.92)$ \\
\hline Mean (SD) & $2.31(1.55)$ & $3.42(2.00)$ & 3.37 (2.29) & $2.05(1.14)$ \\
\hline Median (IQR) & $2.00(1.00-3.00)$ & $4.00(2.00-4.00)$ & $3.00(2.00-4.00)$ & $2.00(1.00-2.00)$ \\
\hline \multicolumn{5}{|l|}{ Exams } \\
\hline $\mathrm{N}^{*}(\%)$ & $1(0.80)$ & $3(1.13)$ & $2(0.93)$ & $3(0.20)$ \\
\hline Mean (SD) & $3.00(-)$ & $1.67(0.58)$ & $2.50(2.12)$ & $1.67(0.58)$ \\
\hline Median (IQR) & $3.00(3.00-3.00)$ & $2.00(1.50-2.00)$ & $2.50(1.75-3.25)$ & $2.00(1.50-2.00)$ \\
\hline
\end{tabular}

* Just one patient per procedure. Medical care: medical consultation/assessing/clinical evaluation. SD: standard deviation; IQR: interquartile range.

performed during the previous five years to the last data available (Table 9) according to SMA-related procedure group stratified by age-group.

Outpatient services accessed over the last year (Supplementary Table 1) or in the last 5-year period (Supplementary Table 2) recorded both ventilatory care and medical care services (diagnose and/or urgency assessment in a pediatric clinic, treatment of central neurons with or without amyotrophic diseases and treatment of neurodegenerative disease). Supplementary Table 3 describes each outpatient SMA-related procedure per group. Although both ventilatory and medical care have been performed in hospitals for all SMA age groups, most procedures were performed in outpatient setting. In all SMA patients, the mean of ventilatory care and physiotherapy, followed by medical care and speech therapy, were the most common outpatient procedures performed per patient last year and since 2015.

Last year (October 2019 - September 2020), 2,137 patients underwent one or more SMA-related procedures at SUS. The median of all SMA-related procedures (ventilatory 
Table 9. HCRU - SMA-related procedure groups, per patient per year, pooled by age at the first claim during the last 5-year (since 2015) $(\mathrm{N}=3,775)$

\begin{tabular}{|c|c|c|c|c|}
\hline Outpatient & $0-6$ months & $>6-18$ months & $>18-36$ months & $>36$ months \\
\hline Total of Patient (N) & 166 & 330 & 324 & 2545 \\
\hline \multicolumn{5}{|c|}{ Ventilatory care/gastrostomy } \\
\hline $\mathrm{N}^{*}(\%)$ & $9(5.42)$ & $32(9.70)$ & $26(8.02)$ & $282(11.08)$ \\
\hline Mean (SD) & $7.49(3.90)$ & $7.46(3.86)$ & $8.29(4.32)$ & $8.34(3.74)$ \\
\hline Median (IQR) & $7.67(6.54-9.88)$ & $7.52(4.99-10.23)$ & $7.85(5.47-12.20)$ & $7.69(5.99-12.37)$ \\
\hline \multicolumn{5}{|l|}{ Physiotherapy } \\
\hline $\mathrm{N}^{*}(\%)$ & $123(74.10)$ & $284(86.06)$ & $274(84.57)$ & $1,809(71.08)$ \\
\hline Mean (SD) & $18.37(24.95)$ & $17.70(25.51)$ & $16.16(28.80)$ & $10.39(18.95)$ \\
\hline Median (IQR) & $11.34(2.49-24.40)$ & $8.63(2.09-25.54)$ & $8.54(2.80-17.50)$ & $3.30(0.84-11.76)$ \\
\hline \multicolumn{5}{|l|}{ Speech therapy } \\
\hline $\mathrm{N}^{*}(\%)$ & $93(56.02)$ & $144(43.64)$ & $113(34.88)$ & $511(20.08)$ \\
\hline Mean (SD) & $4.52(6.44)$ & $5.97(8.02)$ & $4.63(5.76)$ & $4.02(6.12)$ \\
\hline Median (IQR) & $2.31(0.86-5.99)$ & $2.92(1.05-8.35)$ & $2.54(0.89-5.91)$ & $1.58(0.48-4.83)$ \\
\hline \multicolumn{5}{|l|}{ Medical Care } \\
\hline $\mathrm{N}^{*}(\%)$ & $34(20.48)$ & $66(20.00)$ & $54(16.67)$ & $422(16.58)$ \\
\hline Mean (SD) & $2.46(4.06)$ & $1.96(3.01)$ & $2.12(2.53)$ & $2.10(3.82)$ \\
\hline Median (IQR) & $1.01(0.30-1.54)$ & $0.80(0.41-1.93)$ & $1.00(0.60-2.75)$ & $0.82(0.37-1.99)$ \\
\hline \multicolumn{5}{|l|}{ Drugs } \\
\hline $\mathrm{N}^{*}(\%)$ & $8(4.82)$ & $12(3.64)$ & $8(2.47)$ & $8(0.31)$ \\
\hline Mean (SD) & $1.97(1.68)$ & $2.23(1.29)$ & $2.34(1.75)$ & $1.12(0.74)$ \\
\hline Median (IQR) & $1.45(0.58-3.45)$ & $1.90(1.33-3.08)$ & $1.97(1.15-3.48)$ & $0.96(0.70-1.44)$ \\
\hline \multicolumn{5}{|l|}{ Wheelchair } \\
\hline $\mathrm{N}^{*}(\%)$ & $35(21.08)$ & $118(35.76)$ & $148(45.68)$ & $860(33.79)$ \\
\hline Mean (SD) & $0.90(0.48)$ & $0.80(0.56)$ & $0.90(0.74)$ & $0.95(0.86)$ \\
\hline Median (IQR) & $0.86(0.57-1.25)$ & $0.68(0.39-1.15)$ & $0.71(0.39-1.23)$ & $0.70(0.36-1.26)$ \\
\hline \multicolumn{5}{|l|}{ Orthosis } \\
\hline $\mathrm{N}^{*}(\%)$ & $43(25.90)$ & $157(47.58)$ & $185(57.10)$ & $513(20.16)$ \\
\hline Mean (SD) & $2.32(2.14)$ & $2.22(2.42)$ & $1.96(2.42)$ & $1.07(1.20)$ \\
\hline Median (IQR) & $1.64(0.66-3.41)$ & $1.32(0.56-3.06)$ & $1.20(0.55-2.33)$ & $0.63(0.34-1.33)$ \\
\hline \multicolumn{5}{|l|}{ Tests/Exams } \\
\hline $\mathrm{N}^{*}(\%)$ & $1(0.60)$ & $1(0.30)$ & $3(0.93)$ & $7(0.28)$ \\
\hline Mean (SD) & $3.12(-)$ & $1.89(-)$ & $1.14(1.35)$ & $0.85(0.95)$ \\
\hline Median (IQR) & $3.12(3.12-3.12)$ & $1.89(1.89-1.89)$ & $0.60(0.37-1.64)$ & $0.48(0.20-1.14)$ \\
\hline
\end{tabular}

* Just one patient per procedure. Medical care: medical consultation/assessing/clinical evaluation. SD: standard deviation; IQR: interquartile range.

care, speech therapy, wheelchair, orthosis, drug uses, exams, and medical care) performed per patient was similar among all age groups with a tendency to decrease the median of physiotherapy procedures over the age. Considering the percentage of patients undergoing any procedure according to the total number of patients per age group, we found a tendency to increase the percentage of patients submitted to any ventilatory care and wheelchair use and a tendency to decrease in speech therapy procedures and use of drugs (nusinersen), as the patient was getting older.
In the last 5-year period, the number of patients using healthcare resources was 3,775. The mean and median of physiotherapy, orthosis, and exam procedures performed per patient per year showed a tendency to decrease as patients were getting older. Physiotherapy changed from 11.34 (2.49 - 24.40) procedures PPPY in 0 - 6-month-old group to 3.30 (0.84 - 11.76) procedures PPPY in $>36$-month-old group. The median of orthosis was 1.64 (0.66. - 3.41) procedures PPPY in the 0 - 6-month-old group and 0.63 (0.34 1.33) PPPY in >36-month-old group. Exams, such as lumbar 
puncture were mainly performed for younger groups $(0-6$ months and $>6-18$ months). The drug use (nusinersen) appears lower in patients from the $>36$-month-old group when compared to any other age group. Ventilatory care, speech therapy, wheelchair, and medical care procedures performed per patient were very similar along with the age groups. The percentage of patients that needed some ventilatory care seems greater, and the speech therapy and the use of nusinersen seem lower along with age. The percentage of orthosis procedures performed on $>6$ - 18-monthold and >18 - 36-month-old group was higher than the other age group.

Supplementary Table 4 describes each inpatient SMArelated procedure according to the procedures group. Such means are expressed as procedure PPPY stratified by age group.

\section{Discussion}

This study was developed to explore SMA characteristics and SMA resource utilization in the SUS system to identify the main procedures encountered along the patient's journey from outpatient and inpatient procedures. A total of 3,775 SMA patients were identified at the Brazilian Unified Health System (SUS) between 2010 and 2020, and 2,175 SMA patients whether the last year is considered (October 2019 to September 2020). This study suggests that SMA patients demand a great use of public healthcare. Although all age groups have shown an important use of resources, the early onset SMA patients require even more, especially with motor function assistance such as physiotherapy and orthosis and performing exams/tests.

The present study found a large proportion of SMA patients in the southeast and northeast of Brazil. Although these regions represent one of the country's highest densities, the number of SMA cases is not equivalent to the demographic density. It might be due to the discrepancy in SMA reports and/or assistance available across the country's different regions. The consanguinity marriages that commonly happen in these areas, especially in the northeast (Otto et al., 2020), could also contribute to this heterogeneous distribution of SMA cases. Furthermore, this could reflect the disease awareness, due to the distribution of healthcare teams more acquainted with neuromuscular disorders in some locations, or the positive impact of non-governmental organizations.

Considering the outcome found in the present study, such as the cohort's median age and the higher proportion of SMA patients in older groups, it is possible to presume a delay in diagnosing SMA patients. The delay appears to vary according to the severity (type) of SMA. One study showed that the mean delay between the first symptoms until the confirmed diagnosis ranged from 6.3 months to
50 months according to the SMA type, reporting type I as the shortest delay in diagnosis and type III as the most extended delay in diagnosis (Lin et al., 2015). Unfortunately, this still occurs in recent years, as shown by Italian authors (Pera et al., 2020).

Interest in SMA management data and patient characteristics has increased in the past years, due to its debilitating and progressive attributes of loss of quality of life, mortality, and morbidity (López-Bastida et al., 2017) (Mercuri et al., 2018). Special attention has been given to real-world data once ongoing data collection helps fulfill and translate the disease complexity and the applied healthcare resources. Studies worldwide show that HCRU and healthcare costs with SMA patients were substantial (Droege et al., 2020). Although the results of multiple studies always differ to some degree, the average annual direct healthcare and direct non-healthcare costs associated with SMA could reach a value higher than $€ 30,000$ per patient (Armstrong et al., 2016; Larkindale et al., 2014; López-Bastida et al., 2017) in some European countries. To the best of our knowledge, there is no or limited information regarding the healthcare resource utilization of patients diagnosed with SMA treated at the Brazilian Unified Health System.

Medical costs increase with the severity of disease and vary significantly according to the individual patient characteristics (Darbà \& Marsà, 2019). While the youngest children with a more severe form of SMA require intensive care for a shorter time due the high mortality rates of the disease, older patients with less severe disease, in general, require appropriate care for a more extended period. Previous studies have found that infantile-onset SMA is associated with high healthcare utilization, consistent with the severity of disease (Arnold et al., 2015; Tan et al., 2019), especially in nusinersen-treated patients (Droege et al., 2020). Nusinersen was the first disease-modifying therapy approved and available in the Brazilian Unified Health System to treat patients with SMA type I - the most severe type (BRASIL, CONITEC, 2019). Nusinersen-treated patients may have had a more severe disease profile before treatment or may have been more likely to seek support and use healthcare resources.

Historically, the management of SMA relied on supportive care, including neuromuscular, respiratory, orthopedic, and nutritional support. While the collective implementation of these management strategies have had an unequivocal impact on survival, they do not attenuate the underlying neuromuscular decline (Droege et al., 2020). Thus, it is correct to expect that even later onset SMA patients will demand significant care and assistance. Ventilatory care and physiotherapy, followed by the speech therapy procedure, were the most common procedures observed in our study for all groups of age. Indeed, SMA patients without effective intervention uniformly become progressively weaker to the 
point of respiratory failure and may die (Kolb, 2015). Studies have shown that mechanical ventilatory support represented more than $40 \%$ of procedures performed on SMA type I patients (Droege et al., 2020), and costly invasive procedures like tracheostomy are frequently used to manage respiratory failure (Tan et al., 2019).

Weakness and impaired mobility predispose patients to numerous musculoskeletal issues. Early recognition and appropriate management help maintain function, prevent deterioration in vital capacity, and improve life quality (Kolb, 2015). Outpatient services at DATASUS showed an actual number of physiotherapy procedures PPPY in agreement with previous data in the literature, which shows that more than $20-40 \%$ of all healthcare procedures performed on SMA patients in the USA are related to motor rehabilitation (Droege et al., 2020). It is essential to highlight that physiotherapy is reported at the DATASUS database in an aggregated form considering the number of the System of High Complexity Procedures Authorization (APAC) in an SIA sub-system - constituted by individual records of high-cost outpatient procedures (Sanni Ali et al., 2019).

Studies have pointed to hospitalization as one of the highest direct healthcare costs associated with SMA (PeñaLongobardo et al., 2020): 65.9\% of SMA patients and $91.1 \%$ of SMA patients diagnosed before one year old had at least one hospitalization in one year (Armstrong et al., 2016). Our study found that ventilatory care and medical care were performed in a hospital setting for all SMA age groups. However, values were lower than expected when compared to prior studies. An American study showed that the care required to manage respiratory illness in SMA type I often includes invasive ventilatory support and extended hospitalization, with approximately 4.2 hospitalizations annually (Cardenas et al., 2019). The methodology used to assess the inpatient healthcare resource could explain this data discrepancy, such as probabilistic record linkage techniques. (Freire et al., 2015). This method depends on the correct coding of SMA diagnosis, according to ICD-10, and misclassification of SMA cases due to incorrect registration ICD codes is widespread, which could lead to an underestimated number of outpatients SMA-related procedures.

Although there are gaps in knowledge regarding SMA distribution by type, in terms of incidence, SMA type I and II are considered the most frequently occurring SMA subtypes (Mercuri et al., 2018). About 54\% of cases are type I, and 18\% are type II (Arnold et al., 2015)(Klug et al., 2016). Its prevalence of 0.04 to 0.28 per 100,000 is much lower than expected for all SMA (Verhaart et al., 2017). Recent studies estimated a median life expectancy of around one year for type I patients and surviving beyond 20 years for most of type II. Type III life expectancy is considered close to the unaffected population (Verhaart et al., 2017). Thus, it is possible to assume that many early-onset SMA patients are not accounted for because of premature death. On the other hand, it is essential to mention that once patients fulfill the eligibility criteria, it is impossible to detect whether they are alive or dead using this database. However, these are limitations inherent to the methodology adopted in this study.

Among the main limitations of the analysis, it is essential to mention that the quality and integrity of the data collected are proportional to the level of information available in the Brazilian Unified Health System. Moreover, the DATASUS database may not capture services reimbursed by the state and municipality and procedures performed in the private setting or out of pocket. Thus, healthcare resource utilization may have been underestimated for patients seeking care outside the network. Since SMA is a rare disease challenging to diagnose and with a low prevalence, it is expected, as with all retrospective claims database studies, some inaccuracies or missing diagnosis and procedures. The use of a combined claim, including the disease ICD-10 and SMArelated procedure were adopted to mitigate this limitation. SMA is suspected when motor symptoms are present, but several neuromuscular and metabolic conditions can cause muscle weakness and decreased muscle tone. The standard tool for SMA diagnosis is a molecular testing (Arnold et al., 2015; Mercuri et al., 2018), which would probably take time to be correctly diagnosed. Thus, the more recent the patient in the database is, the more difficult it is to fulfill the eligibility criteria, which impacts the number of new SMA cases found in the database, as in recent years (2019 and 2020). Also, 2020 was an atypical year due the COVID-19 pandemic. It is expected a decreasing number of diagnosis and treatment of SMA patients during this period. Finally, data were collected over a limited study period; to the extent that HCRU may not be constant over time, this may lead to underestimating or overestimating the HCRU.

This study provides real-world evidence of SMA patients in the Brazilian Unified Health System. Our results show the important and far-ranging use of healthcare resources for SMA patients among all age-group which appears even higher in early-onset SMA. The data highlights the importance of understanding patient characteristics and would help decision-makers understand the comprehensive effect of this disease on the healthcare system. Further studies might link standards of care with natural history and health economic studies to obtain a broader view of issues surrounding the successful management of SMA, especially with the recent introduction of modifying-disease drugs.

\section{Acknowledgments}

The authors are grateful to Marina Gabriela Birck and Rafaela Ferreira for supporting the analysis plan development and reviews. This study was funded by Roche Brazil. 


\section{Conflict of interest}

Julio Cesar Barbour Oliveira, Alessandra Mileni Versuti Ritter and Guilherme Silva Julian are employees of IQVIA Brazil. Priscila Yazawa, Fabiana Casarin, Veronica Elisabeth Mata, and Nayara da Silva Carlos are employees of Roche Brazil. Edmar Zanoteli is the principal investigator of Firefish and Rainbowfish studies (Roche). Alexandra Prufer de Q. C. Araujo is the principal investigator of Sunfish study (Roche).

\section{Financial support}

This study was funded by Roche Brazil.

\section{References}

Ali MS, Ichihara MY, Lopes LC, Barbosa GCG, Pita R, Carreiro RP, Dos Santos DB, Ramos D, Bispo N, Raynal F, Canuto V, de Araujo Almeida B, Fiaccone RL, Barreto ME, Smeeth L, Barreto ML. Administrative Data Linkage in Brazil: Potentials for Health Technology Assessment. Front Pharmacol. 2019 Sep 23;10:984. doi: 10.3389/fphar.2019.00984.

ANS. (n.d.). Agência Nacional de Saúde Suplementar. Dados Gerais — ANS - Agência Nacional de Saúde Suplementar, 2021. Retrieved January 20, 2003, from http://www.ans.gov.br/perfil-do-setor/dados-gerais

Armstrong EP, Malone DC, Yeh WS, Dahl GJ, Lee RL, Sicignano N. The economic burden of spinal muscular atrophy. J Med Econ. 2016 Aug;19(8):822-6. doi: 10.1080/13696998.2016.1198355.

Arnold WD, Kassar D, Kissel JT. Spinal muscular atrophy: diagnosis and management in a new therapeutic era. Muscle Nerve. 2015 Feb;51(2):157-67. doi: 10.1002/mus.24497.

BRASIL. Ministério da Saúde Comissão Nacional de Incorporação de Tecnologias no SUS (CONITEC). (2019). Nusinersena para Atrofia Muscular Espinhal 5q: Relatório de recomendação. 71.

Campos D, Rosim R, Duva A, et al. Brazilian healthcare record linkage (BRHC-RLK) - A record linkage methodology for Brazilian medical claims datasets (DATASUS). Value Health. 2017;20(5):A321.

Cardenas J, Menier M, Heitzer MD, Sproule DM. High Healthcare Resource Use in Hospitalized Patients with a Diagnosis of Spinal Muscular Atrophy Type 1 (SMA1): Retrospective Analysis of the Kids' Inpatient Database (KID). Pharmacoecon Open. 2019 Jun;3(2):205-213. doi: 10.1007/s41669-018-0093-0.

Chambers GM, Settumba SN, Carey KA, Cairns A, Menezes MP, Ryan M, et al. Prenusinersen economic and health-related quality of life burden of spinal muscular atrophy. Neurology. 2020;95(1):1-10. https://doi. org/10.1212/WNL.0000000000009715

CONITEC. (2019). Protocolo Clínico e Diretrizes Terapêuticas Atrofia Muscular Espinhal 5q Tipo 1 Agosto/2019. 1-34. http://conitec.gov.br/images/ Consultas/Relatorios/2019/Relatrio_-Atrofia-Muscular-espinhal_ CP_46_2019.pdf

Conselho Nacional de Saúde, 2016. (n.d.). Ministério da Saúde. Available from: http://conselho.saude.gov.br/resolucoes/2016/res0510.pdf.

Darbà J, Marsà A. Patient characteristics and hospitalisation costs of spinal muscular atrophy in Spain: a retrospective multicentre database analysis. BMJ Open. 2019 Nov 21;9(11):e031271.

Darbà J. Direct Medical Costs of Spinal Muscular Atrophy in the Catalonia Region: A Population-Based Analysis. Clin Drug Investig. 2020 Apr;40(4):335-341. doi: 10.1007/s40261-020-00897-4.

Droege M, Sproule D, Arjunji R, Gauthier-Loiselle M, Cloutier M, Dabbous O. Economic burden of spinal muscular atrophy in the United States: a contemporary assessment. J Med Econ. 2020 Jan;23(1):70-79. doi: 10.1080/13696998.2019.1646263.

Freire SM, Souza RC, de Almeida RT. Integrating Brazilian health information systems in order to support the building of data warehouses. Rev Bras Eng Bioméd. 2015;31(3):196-207. https://doi.org/10.1590/2446-4740.0666

Julian GS, Rosim RP, Carneseca EC, Rigolon J. Annualized hospitalization rate with natalizumab vs fingolimod in second-line treatment for RRMS in the public healthcare system in Brazil: A claim database approach. PLoS One. 2020 Mar 2;15(3):e0229768. doi: 10.1371/journal.pone.0229768.

Kim CA, Passos-Bueno MR, Marie SK, Cerqueira A, Conti U, Marques-Dias $M J$, et al. Clinical and molecular analysis of spinal muscular atrophy in Brazilian patients. Genet Mol Biol. 1999;22(4):487-92. https://doi. org/10.1590/S1415-47571999000400005

Klug C, Schreiber-Katz O, Thiele S, Schorling E, Zowe J, Reilich P, et al. Disease burden of spinal muscular atrophy in Germany. Orphanet J Rare Dis. 2016 May 4;11(1):58. doi: 10.1186/s13023-016-0424-0.

Kolb SJ, Kissel JT. Spinal Muscular Atrophy. Neurol Clin. 2015 Nov;33(4):831-46. doi: 10.1016/.ncl.2015.07.004

Larkindale J, Yang W, Hogan PF, Simon CJ, Zhang Y, Jain A, et al. Cost of illness for neuromuscular diseases in the United States. Muscle Nerve. 2014 Mar:49(3):431-8. doi: 10.1002/mus.23942

Lin CW, Kalb SJ, Yeh WS. Delay in Diagnosis of Spinal Muscular Atrophy: A Systematic Literature Review. Pediatr Neurol. 2015 Oct;53(4):293-300. doi: 10.1016/j.pediatrneurol.2015.06.002

López-Bastida J, Peña-Longobardo LM, Aranda-Reneo I, Tizzano E, Sefton M, Oliva-Moreno J. Social/economic costs and health-related quality of life in patients with spinal muscular atrophy (SMA) in Spain. Orphanet J Rare Dis. 2017 Aug 18;12(1):141. doi: 10.1186/s13023-017-0695-0

Lunn MR, Wang CH. Spinal muscular atrophy. Lancet. 2008 Jun 21;371(9630):2120-33. doi: 10.1016/S0140-6736(08)60921-6. PMID: 18572081.

Mercuri E, Finkel RS, Muntoni F, Wirth B, Montes J, Main M, et al.; SMA Care Group. Diagnosis and management of spinal muscular atrophy: Part 1: Recommendations for diagnosis, rehabilitation, orthopedic and nutritional care. Neuromuscul Disord. 2018 Feb;28(2):103-115. doi: 10.1016/j.nmd.2017.11.005

Otto PA, Lemes RB, Farias AA, Weller M, Lima SOA, Albino VA, et al. The structure of first-cousin marriages in Brazil. Scientific Reports. 2020;10(1):1-9. https://doi.org/10.1038/s41598-020-72366-z

Peña-Longobardo LM, Aranda-Reneo I, Oliva-Moreno J, Litzkendorf S, Durand-Zaleski I, Tizzano E, et al. The Economic Impact and HealthRelated Quality of Life of Spinal Muscular Atrophy. An Analysis across Europe. Int J Environ Res Public Health. 2020 Aug 5;17(16):5640. doi: 10.3390/ijerph17165640

Pera MC, Coratti G, Berti B, D'Amico A, Sframeli M, Albamonte E, de Sanctis R, Messina S, Catteruccia M, Brigati G, Antonaci L, Lucibello S, Bruno C, Sansone VA, Bertini E, Tiziano D, Pane M, Mercuri E. Diagnostic journey in Spinal Muscular Atrophy: Is it still an odyssey? PLoS One. 2020 Mar 23;15(3):e0230677.

Tan H, Gu T, Chen E, Punekar R, Shieh PB. Healthcare Utilization, Costs of Care, and Mortality Among Psatients With Spinal Muscular Atrophy. J Health Econ Outcomes Res. 2019 Dec 2;6(3):185-195. doi: 10.36469/63185

Verhaart IEC, Robertson A, Wilson IJ, Aartsma-Rus A, Cameron S, Jones CC, et al. Prevalence, incidence and carrier frequency of $5 q$-linked spinal muscular atrophy - a literature review. Orphanet J Rare Dis. $2017 \mathrm{Jul}$ 4;12(1):124. doi: 10.1186/s13023-017-0671-8 


\section{Supplementary material}

Supplementary Table 1. HCRU - SMA-related procedures, groups per patient, per year, pooled by age at the first claim during the last year (from October 2019 to September 2020) (N: 2,137)

Hospital/inpatient

Current age

$\begin{array}{cccc}0-6 \text { months } & >6-18 \text { months } & >18-36 \text { months } & >36 \text { months } \\ 125 & 266 & 215 & 1531\end{array}$

Ventilatory care /gastrostomy $(\mathrm{N}=40)$

\begin{tabular}{lcccc}
\hline $\mathrm{N}(\%)$ & $4(3.20)$ & $4(1.50)$ & $1(0.47)$ & $31(2.02)$ \\
\hline Mean (SD) & $1.00(0.00)$ & $1.25(0.50)$ & $1.00(-)$ & $1.16(0.37)$ \\
\hline Median (IQR) & $1.00(1.00-1.00)$ & $1.00(1.00-1.25)$ & $1.00(1.00-1.00)$ & $1.00(1.00-1.00)$ \\
\hline
\end{tabular}

Medical Care $(\mathrm{N}=56)$

\begin{tabular}{lcccc}
\hline N\% & $10(8.00)$ & $15(5.64)$ & $7(3.26)$ & $24(1.57)$ \\
\hline Mean (SD) & $1.90(1.10)$ & $1.93(1.28)$ & $1.86(0.69)$ & $1.83(1.17)$ \\
\hline Median (IQR) & $1.50(1.00-2.75)$ & $1.00(1.00-2.50)$ & $2.00(1.50-2.00)$ & $1.00(1.00-3.00)$ \\
\hline
\end{tabular}

SD: standard deviation; IQR: interquartile range

Supplementary Table 2. HCRU - SMA-related procedures, groups per patient, per year, pooled by age at the first claim (since 2015) (N: 3,775)

\section{Hospital/inpatient}

\section{Current age}

$0-6$ months

125

$>6-18$ months
266

266

$>18-36$ months
215

215
>36 months

1531

Ventilatory care /gastrostomy ( $\mathrm{N}$ - 287)

\begin{tabular}{lcccc}
\hline N (\%) & $11(6.63)$ & $12(3.64)$ & $7(2.16)$ & $257(10.10)$ \\
\hline Mean (SD) & $0.59(0.35)$ & $0.44(0.27)$ & $0.54(0.29)$ & $0.33(0.30)$ \\
\hline Median (IQR) & $0.54(0.29-0.86)$ & $0.42(0.24-0.51)$ & $0.46(0.34-0.75)$ & $0.22(0.14-0.41)$ \\
\hline Medical Care (N=144) & & & & \\
\hline N\% & $18(10.84)$ & $26(7.88)$ & $12(3.70)$ & $88(3.46)$ \\
\hline Mean (SD) & $0.97(0.64)$ & $1.11(1.18)$ & $1.36(1.64)$ & $0.42(0.52)$ \\
\hline Median (IQR) & $0.78(0.44-1.40)$ & $0.76(0.36-1.33)$ & $0.73(0.26-1.60)$ & $0.23(0.13-0.46)$ \\
\hline
\end{tabular}

SD: standard deviation; IQR: interquartile range

Supplementary Table 3. Description and counting of inpatient SMA-related procedures per patient according to the current age

\begin{tabular}{|c|c|c|c|c|c|}
\hline \multirow[b]{2}{*}{ Group } & \multirow{2}{*}{$\begin{array}{l}\text { Hospital/inpatient } \\
\text { Procedure }\end{array}$} & \multicolumn{4}{|c|}{ Current age } \\
\hline & & $\begin{array}{c}0-6 \\
\text { months }\end{array}$ & $\begin{array}{l}>6-18 \\
\text { months }\end{array}$ & $\begin{array}{l}>18-36 \\
\text { months }\end{array}$ & $\begin{array}{c}>36 \\
\text { months }\end{array}$ \\
\hline \multirow{2}{*}{$\begin{array}{l}\text { Ventilatory care/ } \\
\text { gastrostomy }\end{array}$} & 0407010211 Gastrostomy & 1.11 & 1.33 & 1.00 & 1.12 \\
\hline & 0407010220 Videolaparoscopic gastrostomy & - & - & - & 1.00 \\
\hline \multirow[t]{3}{*}{ Medical Care } & $\begin{array}{l}0301060010 \text { diagnose and/or urgency assessment in } \\
\text { pediatric clinic }\end{array}$ & 1.63 & 1.33 & - & - \\
\hline & $\begin{array}{l}0303040190 \text { treatment of central neurons with or } \\
\text { without amyotrophic diseases }\end{array}$ & 1.45 & 1.43 & - & 1.00 \\
\hline & 0303040203 treatment of neurodegenerative disease & 1.53 & 2.33 & - & 1.00 \\
\hline
\end{tabular}


Supplementary Table 4. Description and counting of outpatient SMA-related procedures per patient according to the current age

\begin{tabular}{|c|c|c|c|c|}
\hline \multirow[b]{2}{*}{ Group } & \multirow{2}{*}{$\begin{array}{l}\text { Outpatient } \\
\text { Procedure }\end{array}$} & \multicolumn{3}{|c|}{ Current age } \\
\hline & & $\begin{array}{l}0-6 \\
\text { months }\end{array}$ & $\begin{array}{l}>6-18 \\
\text { months }\end{array}$ & $\begin{array}{l}>18-36 \\
\text { months }\end{array}$ \\
\hline \multirow[t]{2}{*}{$\begin{array}{l}\text { Ventilatory care/ } \\
\text { gastrostomy }\end{array}$} & $\begin{array}{l}0301050015 \text { monitoring and evaluation of patient submitted to non-invasive } \\
\text { mechanical ventilation }\end{array}$ & 8.39 & 9.62 & 10.58 \\
\hline & $\begin{array}{l}0301050066 \text { implementation or maintenance of home non-invasive } \\
\text { mechanical ventilation }\end{array}$ & 1.00 & 1.00 & 1.00 \\
\hline \multirow[t]{6}{*}{ Physiotherapy } & $\begin{array}{l}0301060010 \text { diagnose and/or urgency assessment } \\
\text { in a pediatric clinic }\end{array}$ & 7.19 & 3.78 & 7.18 \\
\hline & $\begin{array}{l}0302040013 \text { physiotherapy service in patients with respiratory disorders and } \\
\text { systemic complications }\end{array}$ & 2.25 & 3.00 & 4.40 \\
\hline & 0302050027 physiotherapy service in motor changes & 5.08 & 4.29 & 6.07 \\
\hline & $\begin{array}{l}0302060014 \text { physiotherapy assistance in patients with neuro-kinetic- } \\
\text { functional disorders without systemic complications }\end{array}$ & 4.70 & 4.68 & 5.68 \\
\hline & $\begin{array}{l}0302060022 \text { physiotherapy assistance in patients with neuro-kinetic- } \\
\text { functional disorders with systemic complications }\end{array}$ & 5.76 & 7.12 & 7.30 \\
\hline & $\begin{array}{l}0302060030 \text { physiotherapy assistance in disorders of neuro motor } \\
\text { development }\end{array}$ & 7.72 & 4.06 & 6.00 \\
\hline Speech therapy & 0301070113 individual speech therapy & 6.33 & 5.20 & 3.33 \\
\hline \multirow[t]{4}{*}{ Medical Care } & 0301010064 medical consultation in primary care & 1.00 & - & - \\
\hline & 0301010072 medical consultation in specialized care & 2.53 & 2.53 & 2.16 \\
\hline & 0301010137 consultancy/homecare service & - & - & - \\
\hline & $\begin{array}{l}0301010196 \text { clinical evaluation for diagnosis of rare disease } \\
\text { - axis I - } 1 \text { - congenital or long manifestation anomalies }\end{array}$ & 2.65 & 3.00 & 2.00 \\
\hline Drugs & 0604790015 nusinersen 2,4MG/ML injection solution & 3.58 & 3.57 & - \\
\hline \multirow[t]{4}{*}{ Wheelchair } & 0701010029 adult/child wheelchair (standard type) & 1.34 & 1.27 & 1.00 \\
\hline & 0701010037 wheelchair for bath with health seat & 1.50 & 1.20 & 1.00 \\
\hline & 0701010045 wheelchair for quadriplegic - standard type & 1.43 & 1.22 & 1.50 \\
\hline & 0701010207 monobloc wheelchair & - & - & 2.00 \\
\hline \multirow[t]{4}{*}{ Wheelchair } & 0701010223 adult or infantile motorized wheelchair & 2.00 & 1.89 & 1.50 \\
\hline & 0701010231 wheelchair for children in shell & 1.47 & - & - \\
\hline & 0701010240 wheelchair with reclining surface & 1.75 & 1.73 & 1.43 \\
\hline & 0701010258 wheelchair for bath & 1.75 & - & 1.83 \\
\hline \multirow[t]{7}{*}{ Orthosis } & 0701020067 Orthosis infantile for limiting knee with articulated extension & 1.25 & 1.00 & 2.00 \\
\hline & 0701020075 Infantile orthoses for limiting knee movements & 2.59 & 1.25 & 1.00 \\
\hline & 0701020083 Orthosis with distractor (infantile and juvenile) & 2.00 & - & - \\
\hline & 0701020180 Orthosis metallic with or without ischial base (infantile and juvenile) & 2.62 & 1.00 & - \\
\hline & 0701020210 Infantile orthosis articulated & 2.56 & 2.60 & - \\
\hline & 0701020229 Orthosis without articulation (adult) & - & 2.00 & 1.40 \\
\hline & 0701020237 Orthosis without articulation (infantile) & 2.44 & 1.92 & - \\
\hline Exams & 0201010631 lumbar puncture & 2.12 & - & - \\
\hline
\end{tabular}

